\title{
Umbilical Cord Hemangioma with Pseudocyst: An Exceptional Finding
}

\section{Hemangioma do Cordão Umbilical com Pseudocisto Associado: Um Achado Raro}

Ana ROCHA $₫ 1$, Maria do Céu RODRIGUES ${ }^{2}$, Jorge BRAGA ${ }^{1}$

Acta Med Port 2017 Sep;30(9):662-662 - https://doi.org/10.20344/amp.9274

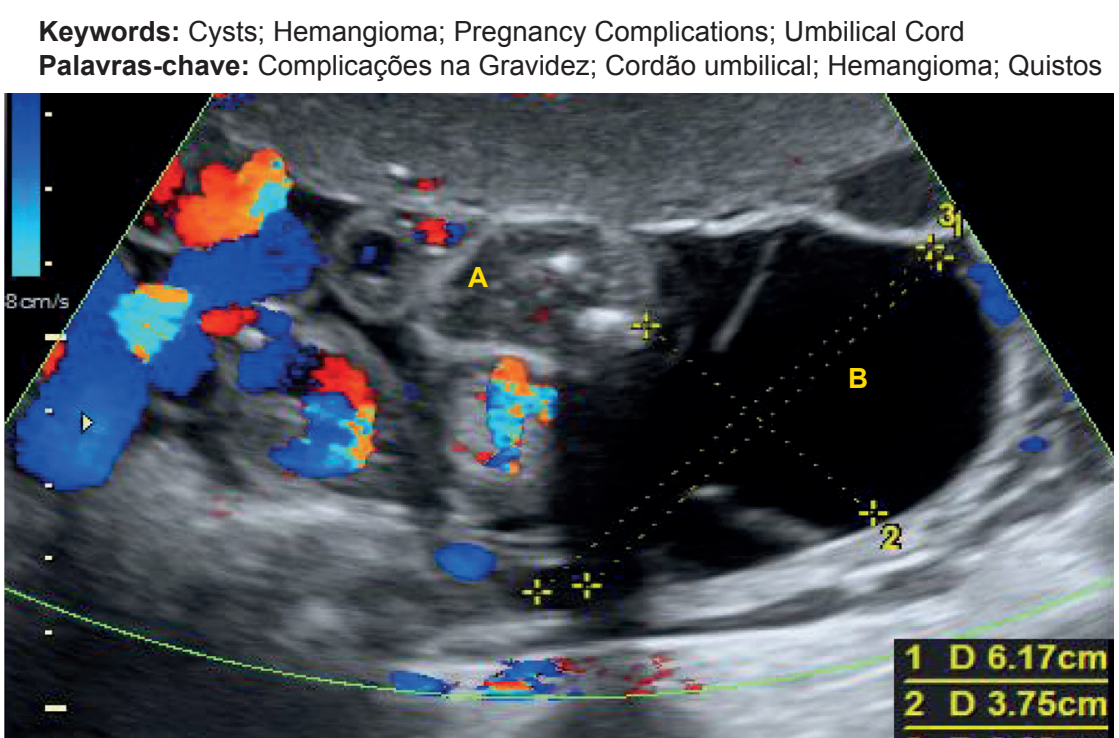

Figure 1 - Ultrasound at $31 \mathrm{~W}$ : the hemangioma presents as an hyperechogenic mass with low blood flow $(A)$ in close relation with a big cystic mass (B)

Healthy 33-years-old woman, nulliparous with uncomplicated pregnancy presents at 23 weeks (W) with umbilical cord cyst diagnosis. Ultrasound without fetal abnormalities, and normal amniotic fluid index. Tight pregnancy surveillance showed progressive size increase of the cyst $(80 \mathrm{~mm})$ associated with a small hiperecogenic mass of the umbilical cord (Fig. 1), with otherwise normal findings. Vaccum-assisted delivery at $39 \mathrm{~W}$ with a healthy male newborn, $3350 \mathrm{~g}$, without skin hemangiomas. Pathology revealed a $50 \mathrm{~mm} \times 45 \mathrm{~mm}$ hemangioma involving two vessels of the cord with associated $10 \mathrm{~mm}$ pseudocyst (Fig. 2).

Hemangiomas arise from proliferation of the primitive angiogenic mesenchyme of the cord and are extremely rare findings. ${ }^{1-4}$ Pseudocysts are often associated because of sion or bleeding. ${ }^{1,5}$
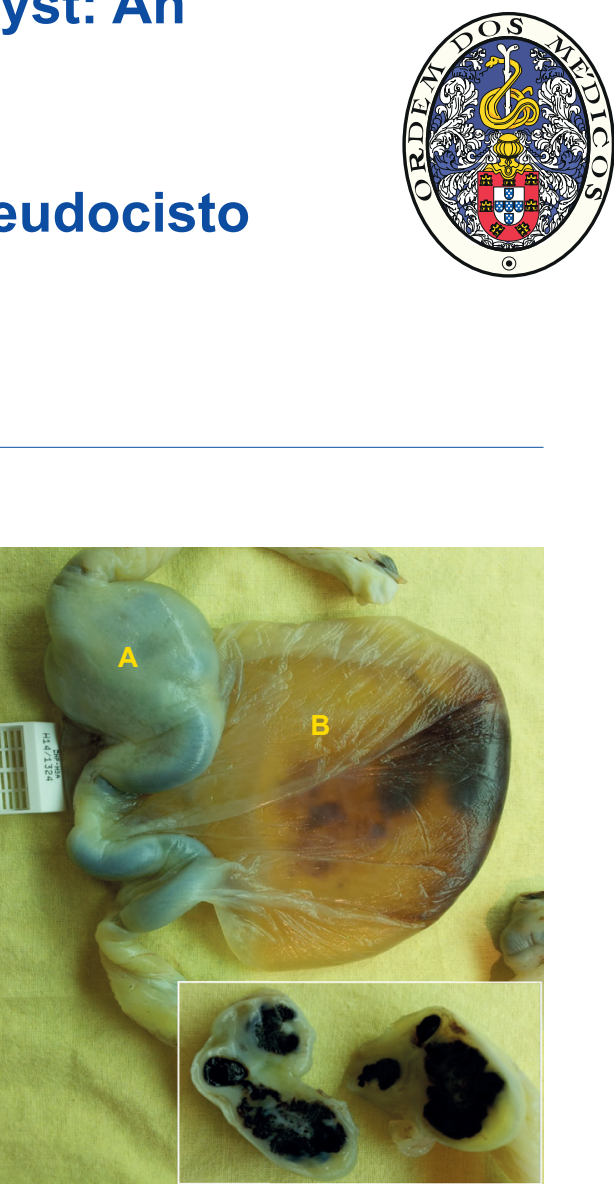

Figure 2 - Pathology findings: the hemangioma with $50 \mathrm{~mm} \times 45 \mathrm{~mm}$ involving two vessels with an associated pseudocyst $(10 \mathrm{~mm})$

the increased vascular pressure,causing transfer of fluid into Wharton's jelly. ${ }^{1}$ They can be associated with chromosomal / congenital defects,,$^{3,4}$ growth restriction, ${ }^{1,3}$ pleural / pericardial effusion,,$^{3,4}$ fetal hydrops,,$^{1,3}$ cutaneous / systemic hemangiomas ${ }^{1,4,5}$ and fetal demise..$^{1-5} \mathrm{~A}$ mortality rate of $35 \%{ }^{5}$ has been descibed, mostly by cord compression, tor-

\section{DATA CONFIDENTIALITY}

Informed consent was duly obtained from the patient.

\section{CONFLICTS OF INTEREST}

All authors report no conflict of interest.

\section{REFERENCES}

1. Sepulveda W. Prenatal diagnosis and management of umbilical cord abnormalities. UpToDate. [accessed April 2017] Available from: https://www. uptodate.com/contents/prenatal-diagnosis-and-management-of-umbilical-cord-abnormalities.

2. Matsuda S, Sato Y, Marutsuka K, Sameshima H, Michikata K, Ikenoue T, et al. Hemangioma of the umbilical cord with pseudocyst. Fetal Pediatr Pathol. 2011;30:16-21.

3. Smulian JC, Sarno AP, Rochon ML, Loven VA. The natural history of an umbilical cord hemangioma. J Clin Ultrasound. 2016;44:455-8.

4. Papadopoulos VG, Kourea HP, Adonakis GL, Decavalas GO. A case of umbilical cord hemangioma: doppler studies and review of the literature. Eur J Obstet Gynecol Reprod Biol. 2009;144:8-14.

5. Iglesias-Deus A, Pérez-Muñuzuri A, Urisarri A, Bautista-Casasnovas A, Couce ML. Umbilical cord and visceral hemangiomas diagnosed in the neonatal period. A case report and a review of the literature. Medicine. 2016;95:e5196.

1. Serviço de Ginecologia/Obstetrícia. Centro Materno Infantil do Norte. Centro Hospitalar e Universitário do Porto. Porto. Portugal.

2. Unidade de Diagnóstico e Terapêutica Pré-Natal. Centro Materno Infantil do Norte. Centro Hospitalar e Universitário do Porto. Porto. Portugal.

$\bowtie$ Autor correspondente: Ana Rocha. ana_mr_rocha@hotmail.com

Recebido: 06 de junho de 2017 - Aceite: 18 de agosto de 2017 | Copyright @ Ordem dos Médicos 2017 